\title{
Origin, Use and Meaning of the Innovation Diamond
}

\author{
http://doi.org/10.21272/bel.5(4).48-58.2021
}

Fernando Alonso Ojeda Castro, ORCID: https://orcid.org/0000-0002-3271-0707

Professor, researcher, economist, specialist in International Economics of Southeast and Central Asia, Pilot University of Colombia, Faculty of Economic and Administrative Sciences, Business Administration Program, Colombia

\begin{abstract}
This document seeks to present the instrument known as the DIAMOND OF INNOVATION and its "green version", reveals the genesis from the results shown with the generation of the collection of books called: ASIAN FIRMS. Using these eight books makes it possible to discover the business model of the central countries (PR China, Republic of India) and Southeast Asia (Japan, South Korea, R. China-Taiwan, Singapore, Vietnam), focusing on continuous Innovation. This process, which tested and perfected the instrument, is accompanied by companies from the industrial and Colombian primary sectors. The tool shows its ability to establish a diagnosis in a city, country, company in terms of Innovation and establish a strategy based on the eight points of the Diamond and accompany it with a hierarchy or strategic priority. To this end, the use of secondary tools is established, such as the STRATEGIC MOTHER MATRIX. It detects the behavior of the leading countries for each of the Diamond points, becoming "good practices", and determines the backwardness or practices to improve, prioritizing each strategy to be developed, seeking to advance on the subject of Innovation. With the advancement of research, sponsored from the beginning by the Universidad Piloto de Colombia and its Business Administration program and research partners such as Grupo SASA and some farms in the Ubaté valley (Department of Cundinamarca), dedicated to the main production focused on In dairy, the "green" version of the Innovation Diamond is tested and launched, its reason for being: to prevent Innovation in a country, city, company, from being accepted simply for being Innovation, without considering its impact in the environment.
\end{abstract}

Keywords: Green Diamond, Southeast Asia, R + D + I, Environment, Diamond indicators, Diamond Chart, Strategic Mother Matrix, Cobweb of Innovation.

JEL Classification: O3, O32, F64, Q56.

Cite as: Ojeda, F.A. (2021). Origin, Use and Meaning of the Innovation Diamond. Business Ethics and Leadership, 5(4), 48-58. http://doi.org/10.21272/bel.5(4).48-58.2021.

Received: 29 October 2021

Accepted: 10 December 2021

Published: 30 December 2021

Copyright: (C) 2021 by the author. Licensee Sumy State University, Ukraine. This article is an open access article distributed under the terms and conditions of the Creative Commons Attribution (CC BY) license (https://creativecommons.org/licenses/by/4.0/).

\section{Introduction}

This first installment seeks to explain in its basic concepts the genesis and scientific support of the tool to be used: The Innovation Diamond, with each of the eight points, determines the importance of these as assessment support against cases related to Innovation, be it for a Country, City, Company or business sector. In addition, it determines the different scopes it may have and finally determines priority strategies in this matter to be applied. The Innovation Diamond", where the graphic structure of the same appears, with its eight points. In the second part, the operative part of the tool will be shown, where the questions that it can answer at least "QUESTION THAT THE DIAMOND OF INNOVATION TRIES TO SOLVE" and how it can become an aid for the diagnosis are shown. From this tool, it is explained how it is possible to know the "status of innovation", this purpose is acquired at the level of a country, city, business sector or company. It is allowed to obtain this result, with a matrix that receives the integral information of the points of the Diamond, called "Mother Matrix", it is shown how this is built, from the results of one of the points of the Innovation Diamond, the of Global Competitiveness, see Table 1.

Once the component and essential actions of the Innovation Diamond have been explained, the genesis and creation of its "Green Version" is revealed; in its basic graphic scheme, it is found in Table 2 (Appendix 1). The Green Diamond of Innovation". That is to say, the Diamond, which becomes in its higher phase, an Innovation diagnostic tool for a Country, city, business sector, company, where it reviews the environmental impact that innovation can create. Like its basic version, it diagnoses but, reaches the phase of prioritizing 
strategies depending on the ecological impact that this innovation can produce, according to this after being reviewed with the use of the Green Diamond, at the level of GREEN INNOVATION, INNOVATION TO BE REFORMED, INNOVATION REJECTED.

Finally, understanding that Innovation should not be accepted per se, without taking care of the environmental impact. With the advancement of research, sponsored from the beginning by the Universidad Piloto de Colombia and its Business Administration program and research partners such as Grupo SASA and some farms in the Ubaté valley (Department of Cundinamarca), dedicated to the main production focused on In dairy, the "green" version of the Innovation Diamond is tested and launched, its reason for being: to prevent Innovation in a country, city, company, from being accepted simply for being Innovation, without considering its impact in the environment. This "green version" evaluates, detects, and raises the possibility of obtaining an Innovation, only considering its impact from its start-up on the environment. As a result of this research, the Innovation Diamond has been the conceptual support of the Seedbed of the Business Administration Program, degree projects ${ }^{1}$, technical reports ${ }^{2}$, etc., managing to become a tool for use, with own methodology and with specific achievements, aimed at companies, students (Tubers, 2020), academia, becoming a means of R + D + I interface, bringing the real sector closer, with the State and the University understanding that from the university, there are problems to be solved at the company, city and country level, and the Innovation Diamond is used as a means of working with the students of the seedbed, generating spaces for formative research.

\section{Origin of Innovation Diamond}

The origin of the tool is the product of the work of twelve years, which have been dedicated to studying the business model, associated public policy, culture, education, of the countries of Southeast Asia, and Central Asia. The results are found in some resulting papers, lectures given (Tubers, 2020) and the collection of books known as "ASIAN FIRMS": "la Ciudad más grande del mundo Chongqing" (OJEDA(b), 2014); "Despegue de las grandes marcas y estrategias japonesas" (OJEDA(c), 2014); "La evolución histórica del modelo de las Firmas Asiáticas" (OJEDA(d), 2014); "LA CRISIS ASIÁTICA" (OJEDA, F.A., 2014); "El nuevo milagro asiático, del destrozo total y el estado fallido al último modelo del éxito empresarial asiático" (OJEDA(e), 2014); "Bangalore el Silicon Valley de la India (OJEDA(f), 2014), El modelo empresarial de la China del siglo XXI" (OJEDA(g), 2014); "El secreto mejor guardado de Asia: TAIWAN" (OJEDA(h), 2018); plus the book on International Business: "Entorno de los Negocios" (OJEDA(i), 2015).

From this investigative work, the tool known as "The Diamond of Innovation" was generated. With the analysis of countries led by R.P. China, Japan, Taiwan (ROC), South Korea, Singapore and Vietnam, it was established that they had common patterns that allowed their companies and work allied with the State to stand out, from this process the Diamond with eight (8) points and that answered the following question:

On what variables does the Innovation of a country, city, sector, company, region mainly depend?

$>$ De la Innovación, de una estructura empresarial, su difusión e inversión en maquinaria y equipo, de un país, ciudad, sector, region [Innovation in a business structure, the diffusion and investment in machinery and equipment, within a country, city, business sector and specific region].

$>$ Its Take Off, under its business principles and structures.

$>$ The governmental Institutions of permanent support to the Company and associated Education.

$>$ Strict compliance with its regulations, at the head of its Magna Carta or Constitution.

$>$ The sectors that have been leading and positioning themselves with their companies nationally and internationally, thanks to technological progress, incorporated engineers, focused on the creation of continuous added value of their products, supplies and services.

$>$ The geographic specialization of its industries, accompanied by the construction of spaces in the manner of technology parks, with its own multimodal structures for loading and unloading of merchandise, universities and State Institutions of financial, logistical, legal support and continuous specialized Research.

\footnotetext{
${ }^{1}$ This year 2021, the Business Administration Program received and endorsed works with a degree option, with the use of the Innovation Diamond as conceptual support, the following works: CASE COLOMBIA: COMPARATIVE ANALYSIS IN MATTER OF INTELLECTUAL PROPERTY 2017-2018 of the student Luis Santamaria; COMPARATIVE ADVANTAGES WITH THOSE THAT COLOMBIA HAS AND THAT ALLOWED THE SUSTAINABLE INCREASE OF THE TOURISM SECTOR DURING THE PERIOD 2017-2019 of the student Maria Fernanda Valero.

${ }^{2}$ During the years 2019 and 2020, several technical reports were made to companies, which resulted in innovation strategies with new processes and value chains to companies such as the SASA Group in Colombia, for this the Innovation Diamond was used, which allowed the diagnosis in innovation of the company, to then establish the priority strategies to follow, which were included in the last report of 2020, to test the Diamond in its "green" version, which also verifies how the processes, innovated products, generate greater or lesser environmental impact : Analysis and Strategic Projection of GRUPO SASA SAS, based on an approach, contributed by the Innovation Diamond (2019); The Environmental Impact, as a point of reference for the Innovation Diamond (2020).
} 
$>$ Its basic educational training centers, from where creativity as a skill and its vocation to higher education training focused on the area of Engineering are encouraged.

$>$ Institutions to support the Company from the formation of the Specialized Human Resource to the Funding of the entrepreneurial Company, and the placement, commercialization of products, supplies, services, of mature companies.

$>$ The media and organizations that are part of the State-private sector gear.

$>$ The consolidation of companies-brands, inside and outside the country of origin, at an industrial level, consolidating itself as a source of national wealth and creation of patents.

$>$ To respect, monitor, from every sector of society, the use of human, financial, and logistical resources, intended for the development and implementation of plans, programs associated with the dissemination, management, and maintenance of Innovation, as a source of wealth, job creation, better income and industrial advancement.

The maturation-stability periods of capitalism and its resulting technologies.

$>$ Market and relative prices of production factors.

The dynamics of Tangibles and Intangibles companies.

$>$ The consolidation of business subsectors, proactive to the continuous added value in their products, supplies, services, processes, source of the "Orange Economy".

$>$ The relationship between the Company and the Consumer.

$>$ Telecommunications, as part of an integrated cybersecurity system, which guarantees respect for the privacy of users.

$>$ Promoting Disruptive Innovation, which opens a path to entrepreneurship and savings in research costs for large firms.

$>$ The resulting Networkings, focused on the Open Innovation strategy.

$>$ Every resulting process minimizes the environmental impact, under the strategic principle of Green Innovation.

Deducing from the above that: The Innovation of a business structure, of a country, city, sector, region, depends mainly on: Competitiveness, the Degree of Openness of the Economy, its contribution to GDP, the Level of Education, the Number of Engineers - year, the Number of patents year, Cybersecurity and Corruption, where any resulting process minimizes the environmental impact (OJEDA(a), 2019).

\section{Construction and Support of the Innovation Diamond}

These points or references of Innovation need an assessment, facilitating their traceability, and subsequent strategic-tactical approach as a reference source, compared to what should be considered ideal in terms of Innovation, of a business structure, of a country, city, sector, or region.

Innovation Indicators. The resulting variables in terms of Innovation, with which the Innovation Diamond has, will be evaluated through an Indicator of high source and credibility, by the study of the respective subject and the systematic monitoring supported by Institutions supranational, national, regional, public and private capital. The chosen Indicators with their respective variables that they represent are:

The Global Competitiveness Index (GCI). Established by the World Economic Forum, it focuses on analyzing Global Competitiveness, clearly marking its relationship with Innovation. Its last report was that of 2018. Its sub-indicators or pillars include macroeconomic environment, Institutions, Infrastructure, health and Education, efficiency in the goods market, efficiency in the labor market, market size, business sophistication, financial market development, technological preparation, education, and training of High Quality and the same Innovation (World Economic Forum).

GDP. This indicator of Wealth of the countries is created annually by the World Bank, recognized worldwide as GDP or Gross Domestic Product. It uses the indicator of purchasing power parity (PPP), this technical element, manages to compare this value between countries of the world, avoiding having as a barrier the price levels of each country, according to the internal inflation of each one (WORLD BANK).

Open Economy (ILC). Its indicator is the Index of Economic Freedom (ILC), which observes the degree of closure or opening of an economy, calculated annually, is created by the Heritage Foundation and the Wall Street Journal (WSJ). Its four sub-indices or pillars are: "Rule of Law, Government Size, Regulatory Efficiency and Market Opening" (Journal). Also known as the "OPEN ECONOMY" indicator. Determinant as observed, the degree of openness and tendency facilitates the exchange of goods, services, inputs of a country with the rest of the world. 
Likewise, due to the tendency towards open innovation, it is essential to be flexible with the commercial opening of the territory under study. This degree of economic freedom impacts the fields of knowledge, financing, skills, specialization, which allows SMEs to be located in the world, with a certain degree of commercial openness, communication and mobility of knowledge and people, specialized laboratories and/or from the Academy itself (OECD, 2010).

Corruption Perception Index (IPC). Known as the Corruption Perceptions Index (CPC), this indicator seeks to absorb the country's perception of corruption. In countries like the R.P. China, this type of crime is punishable by the death penalty or under the modality of life imprisonment and forced labor (EBDRUP, 2014). This indicator is associated with the use of public resources and respect for their due use, which, in our case, is to observe their use and their application in Plans, programs associated with Innovation. Its latest version, that of the year 2018. Its generator is the NGO known as Transparency International (International).

Year Engineers (IA). One of the indicators par excellence in the world in terms of educational quality in higher education reflects the preference and popularity in American universities by all the students of the World (TOP UNIVERSITIES, World University Rankings). Another indicator will be used from the date, which considers this qualification and educational preference to complement this data that speaks of Human Capital in Innovation, under profiles directly involved, due to their training. These are the "Fields of study of students from selected places of origin, 2009/10-2018/19".

The same is achieved by the Institute of International Education in the United States, the version of 2019 is taken as initial support. It takes this, the origin of the different students who came from outside the country to study at American universities, and still determines Study areas: Business and Management, Humanities, Social Sciences, Education, Applied Fine Arts, Health Professions, Intensive English. For the document and the Diamond, Science, Technology, Engineering and Mathematics will be used as indicators, which are part of the so-called "STEM", by the first letters corresponding to the words in English that treat each of these areas (Open Doors). One should consider that the research work that gave rise to the Innovation Diamond, from the epistemological base, shows that Human Resources related to Innovation in Vietnam, PR China, Japan, Taiwan (ROC), Singapore, South Korea are in a high percentage of the profile associated with engineering. However, from this same study, mathematics, science, technology are equally visible in these profiles, practical support of their large multinationals, originally from these countries (OJEDA(b), 2019).

Global Cybersecurity Index (GCI). In the information society and Big corporate data, respect for the use and implementation of data collection systems is decisive, generating an environment of trust towards the company and the technological environment surrounding it. Its Indicator, the Global Cybersecurity for this point of the Diamond, is emanated from the United Nations and its organism in charge of Telecommunications, International Telecommunications Union or ITU (ITU, International Telecomunications Union).

Global Index of Cognitive Skills and Educational Achievement. For its acronym in English IHCLE, this indicator is achieved by the multinational PEARSON, in collaboration with the business publication, The Economist Intelligence Unit (EIU), through what is known as The Learning Curve, which takes up the results of the TIMSS, PIRLS and PISA tests (Worlds of Education, 2015). Due to issues associated with the operationalization of its strategic alliances in the world, the Multinational has not published it since 2014. One should consider that the investigative work that gave rise to the Innovation Diamond, from the epistemological base, shows that the Human Resources related to Innovation in Vietnam, PR China, Japan, Taiwan (ROC), Singapore, South Korea are found in a high percentage of the profile associated with Technology, business, and Database skills. Its global business structures, its Research and Innovation centers, and its educational approach, from basic level to its higher academic degrees, attest to this (OJEDA(b), 2019). Therefore, a new indicator is used that takes the elements above, called Global Skills Index 2020 (GSI). Its analytical base comes from sixty countries, which collected information from some eighty million students, using the COURSERA platform, created in 2012 by Stanford University professors Andrew Ng and Daphne Koller, which became a platform for courses in the Universities of Pennsylvania, Michigan, Princeton and of course Stanford. Today, around 220 world-class universities are offering their courses in this way to fifty-five countries, an increasingly widespread trend of COVID-19 in the world (Coursera, s.f.).

\section{The Innovation Diamond Chart}

Each of these points represents, groups, the variables on which Innovation depends, according to the information that was collected, from the STATE OF THE ART (OJEDA(a), 2019) and the Asian Innovation model, the basis for the formation of the INNOVATION DIAMOND, (Figure 1). 


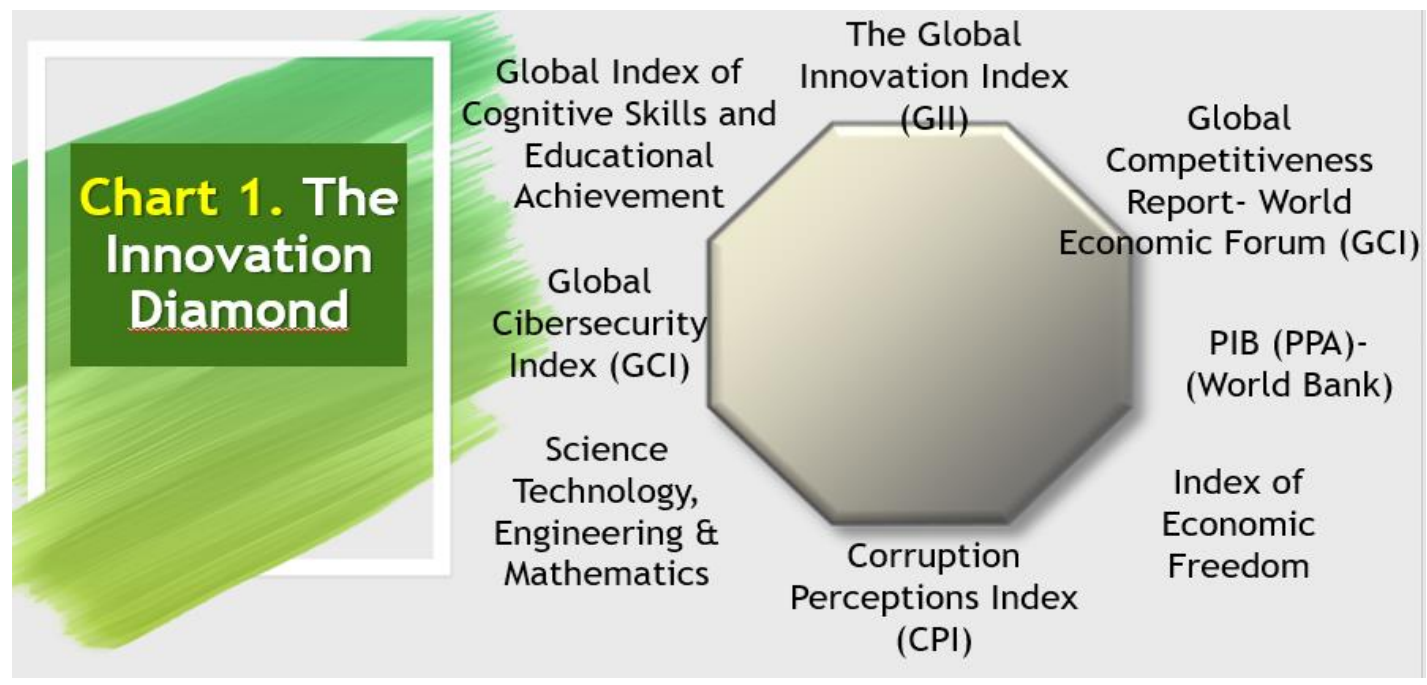

Figure 1. The Innovation Diamond

Source: Report "State of the Art and Theoretical Framework, COMPANIES AS A REFERENCE IN THE MATTER OF INNOVATION AND INTERNATIONAL COMMERCIAL MANAGEMENT: a vision in front of the exchanges from Bogotá, Colombia”. Pilot University of Colombia. June 26, 2019 (OJEDA(a), 2019).

\section{Questions that the Diamond of Innovation Tries to Solve}

It seeks to solve the following questions: What are the paradigms in terms of Innovation to follow worldwide TODAY in countries, cities, companies? What priorities in terms of associated Strategy MUST we implement, in our country, region, company, business sector? What are our GREATEST WEAKNESSES, in terms of innovation, that occur in our country, region, Company, business sector?

Results and Strategic Direction. The results are grouped for each point of the Diamond and grouped in five (5) columns to achieve the final results. The first contains the respective indicator: Global Competitiveness, GDP, Open Economy, etc., see example Table 1, with the sub-indicator "The Global Competitiveness". Below each of these, the sub-indicators, part of the respective indicator are observed. The second column, called "International", allows observing the level of qualification that each country has at an international level; If the front is found with a "black dot", it means that it is a reference in this sub-indicator to follow in its good practices. On the contrary, if the point is red, it indicates that the country, city, company, the business group analyzed, must implement a strategy to correct, improve, implement an Innovation associated with the respective sub-indicator, see example Table 1.

The third column shows the chosen country, in this case, "Colombia". Red dots indicate strategic priorities. These data are obtained from the results obtained by the indicator in the chosen country for each sub-indicator; see example Table 1. The fourth column shows the chosen company; for the case, it was "El Grupo SASA", a company with which Work has been carried out since 2019. After having answered a survey related to each sub-indicator, it showed the level of qualification for each point. Then, it was determined, according to the results shown, which were the priorities that should be strategically implemented. Finally, in the last column, from left to right, called "STRATEGIC RATING", with a rating ranging from 1 to 3 , it will be determined within these shortcomings associated with Innovation, which is a priority, which will not only allow programming the most important - priority, but rather, schedule resources (financial, logistical, human, human), associated with this strategic path to follow, see example Table 1 (OJEDA(b), 2019). 
Table 1. Example of a Strategic Mother Matrix, with the Sub-Indicator "The Global Competitiveness"

\begin{tabular}{|c|c|c|c|c|}
\hline \multicolumn{5}{|c|}{ STRATEGIC MOTHER MATRIX } \\
\hline Indicator (Pillar/Source) & & & & \\
\hline The Global Competitiveness & INTERNATIONAL & COLOMBIA & $\begin{array}{l}\text { GROUP } \\
\text { SASA* }\end{array}$ & $\begin{array}{c}\text { STRATEGIC } \\
\text { PRIORITY }\end{array}$ \\
\hline Finance System & $\bullet$ & & & 1 \\
\hline Innovation Ecosystem & $\bullet$ & & $\bullet$ & 3 \\
\hline Macroeconomic Stability & $\bullet$ & & $\bullet$ & 3 \\
\hline Infraestructure & $\bullet$ & $\bullet$ & $\bullet$ & $3 * *$ \\
\hline Products Market & & & $\bullet$ & 3 \\
\hline Institutions & $\bullet$ & $\bullet$ & & 2 \\
\hline Information Technology and Communication & $\bullet$ & $\bullet$ & $\bullet$ & 3 \\
\hline Education & $\bullet$ & & & 2 \\
\hline Health & $\bullet$ & & & 2 \\
\hline Entertainment & $\bullet$ & & & 2 \\
\hline
\end{tabular}

Source: OJEDA, F.A. (2019, December). Analysis and Strategic Projection of GRUPO SASA S.A.S, based on an approach, contributed by the Innovation Diamond. Research Project: Companies as a reference in the matter of innovation and international commercial management: a vision in front of the exchanges from Bogotá, Colombia. Business Administration Program. Research Office. Pilot University of Colombia

\section{The Green Diamond: Innovation, with Minimum Impact on the Environment}

Continuing with the research on the use and strategic impact of the Innovation Diamond, the second year of the work with the Company "Grupo SASA", part of the Innovation Diamond and its eight points, determine the impact of innovation on the environment, within a country, city, business group or company (as is the case study). According to the results, this "green version" of the Innovation Diamond generates suggestions according to the levels of "severity" of the environmental impact resulting from the implementation of an innovation, the three levels are: GREEN INNOVATION, INNOVATION TO BE REFORMED, INNOVATION REJECTED.

Innovation Diamond Green Indicators. The indicators of Innovation Diamond have an Indicator whose origin and credibility are high, due to the systematic monitoring in the global institutions, of capital mixed and private. Next, its basic origins are resumed, and then its transition to its green valuation is explained see Table 2 (Appendix 1). To achieve this "green conversion", each sub-indicator, which are parts of the central indicator, which are part of each of the eight points, is taken, subjecting them to an environmental impact assessment before implementing the Innovation see Table 2 (Appendix 1). This point-to-point study is the result of the evaluation and testing with the SASA Group as the object of analysis.

Valuation-Construction. An update of the Innovation Diamond was developed, in terms of its eight points, thereby making it possible to show the importance of each of them, compared to Innovation and its ability to evaluate it in a city, region, country, sector, company, allowing to formulate the questions that will enable knowing the degree of the environmental impact of an Innovation, resulting in its final version, Table 2 (Appendix 1). Then, after taking the stage of answering the questions, the level of the city, region, country, sector, company is reviewed: GREEN INNOVATION, INNOVATION BY REFORM and INNOVATION REJECTED. Depending on the grade and the evaluation, this is accepted, adjustments are requested or, the last level rejects it due to its imminent environmental impact and the number of reforms that it would imply to implement.

Environmental Impact Levels. Once the evaluation face is finished, the questions are applied by each point of the Diamond. After the individual evaluation, it will be possible to know the environmental impact that an Innovation in progress, to be put into operation, can create in a country, city, business sector, company. According to the results, suggestions may be made, prioritizing them, according to the results that can be considered in three levels: GREEN INNOVATION, INNOVATION TO BE REFORMED, INNOVATION REJECTED.

Green Innovation. It meets at least $80 \%$ of the requirements, evaluated by the Green Diamond. It can and should be put into action. It must have instruments for continuous monitoring and, if necessary, adjustments.

Innovation to Reform. It meets at least $40 \%$ of the requirements, evaluated by the Green Diamond. It cannot and must not be set in motion. You need to make the suggested changes to reach at least $80 \%$ of the assessed requirements. Likewise, it must have continuous monitoring instruments and determine a schedule of actions and personnel in charge associated with the required modifications. 
Innovation Rejected. It does not meet at least $40 \%$ of the requirements evaluated by the Green Diamond. It cannot and must not be set in motion. Their actions could create severe environmental damage. Its structure should be reviewed, and a new version should be considered from scratch, emphasizing the unfulfilled items.

\section{Evaluation-Testing of the Green Impact from the Diamond Points}

Experimenting with the Innovation Diamond to bring it to its "green" structure is done through the evaluation of the process - products, services to be placed in the country, city, business sector, company, point to point, with the respective questions, Table 2 (Appendix 1): from the Point of Corruption, Human ResourceEngineers, Education, Open Economy, Economic Growth, Cybersecurity associated with green innovation, Intellectual Property with innovations related to the control of waste throughout the operation/process, Competitiveness with the mobility of products/supplies/clients/workers and ecologically productive areas, Environmental PPP Alliances, waste reuse, $80 \%$ of them, which also improve productivity and lower costs variable and fixed, technologies, products for 2021 with low environmental impact are being integrated into the strategic plan, we are working with logistics, public services, which comply still with environmental standards. With this methodology advanced in this diagnostic phase, associated with the environmental impact of innovations, due to the use of products, processes, services, the testing phase is passed, verifying the observed environmental impact. Finally, it will adapt to a strategic adjustment, which introduces the pertinent modifications, according to the previous qualification of the environmental impact levels: GREEN INNOVATION, INNOVATION BY REFORM and INNOVATION REJECTED.

Organizational Achievements of the Green Approach. The "Innovation Diamond" tool, in its original version and its "green" version, seeks to become diagnostic support. I also managed to detect the strategies to follow and know which priorities. It has been used with cases of countries during 2019-2021 since, through the Mother Matrix (Table 1), the case of Colombia and Costa Rica and the reference countries or good practices worldwide were studied for each point of the Diamond. Likewise, it works with a business group (four companies) called Grupo SASA. It has also been used, with the case of farms in the Colombian countryside (twenty in total), in the Municipality of Sutatausa, province of Ubaté, Department of Cundinamarca in Colombia, which have livestock as their main micro-business activity (OJEDA, F.A., 2020). Therefore, the scope of the Tool has allowed achieving: re-doing, adapting the strategic plan, focused on integral processes that include making, structuring green value chains behind sub-brands and proposing strategies for displaying products and associated processes to "Clean Industry".

Integrate intra-organizational processes, where "bottlenecks" are detected, since the farms intensive in livestock and the SASA Group observed that, to a greater or degree level, there are intra-firm processes, in some, it is fulfilled partially or totally, that the environment is respected, but there are areas (Grupo SASA), Fincas, that develop projects with a high dose of creativity and by placing products with partial added value, it does not bring with it a respect for the environment, or totally or partially, colliding with what has already been achieved with other processes, raw materials obtained, which reach this phase with green added value.

Detect the lack of educational level, which is needed to undertake tasks, plan, organize, direct, evaluate processes focused on continuous innovation projects and assess their environmental impact with these new processes. It is possible to detect and raise educational shortcomings and what type of education is required to carry out these processes more efficiently and effectively. In a complementary manner, it has been possible to raise the current needs for future hiring of personnel to adapt to these detected needs. On the other hand, it has been allowed to choose possible strategic alliances, establishing a Networking with companies that adapt both to this restructuring, as a focus on innovation, where they contribute green added value, in the case of outsourcing or being the case, a world sourcing. Likewise, the Innovation Diamond manages to establish the weaknesses or strengths to be worked on, in matters of State institutions, at the national, regional, local level, which after observing them, allow it to be possible to propose actions to improve these, if in the case, offer improvements in them and/or, determine the option to assume them from the real sector, overcoming in some instances the endemic deficiencies of some of these State structures.

At a macro level, the Diamond showed its ability to detect the existence of "good practices at the global level", observing in this regard, what has been achieved by example countries at the eight-point level and its impact on innovation, at the level of: Cybersecurity, Open Economy, Education, Transparency, Economic Growth, Competitiveness, Intellectual Property, and contribution of Human Resources. After detecting the difference between good practices worldwide and what has been done in the country, or in a city, chosen, chosen, where the companies or the company to be analyzed are located (called this space, as "The Gap of Innovation"), 
within the resulting graph (Cobweb of Innovation, see Figure 2), we look for those priorities that are in the red space of part of the country, city analyzed, and propose strategies to follow.

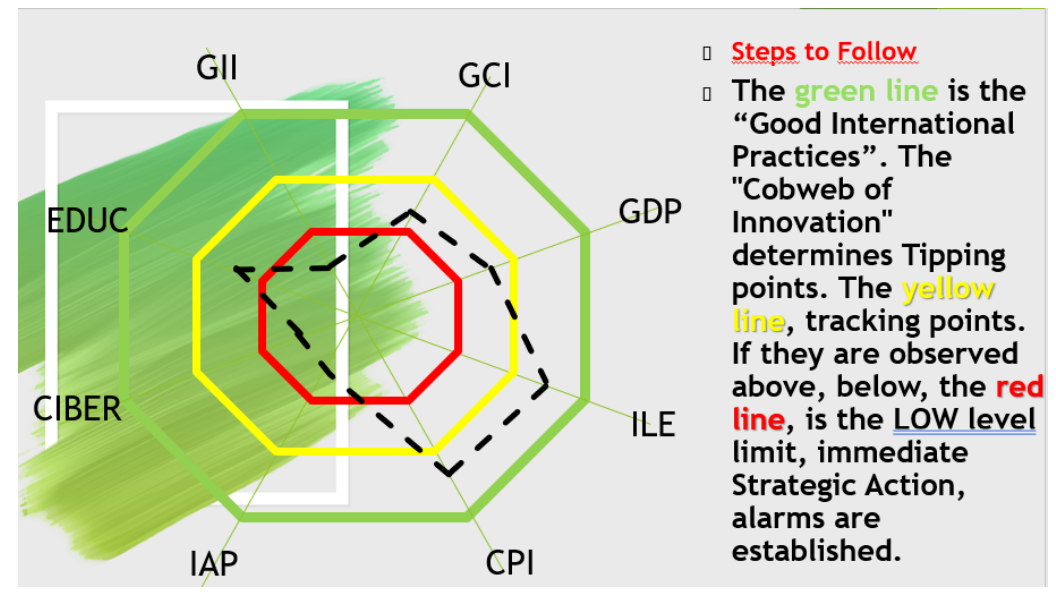

Figure 2. The Cobweb of Innovation

Source: Report "State of the Art and Theoretical Framework, COMPANIES AS A REFERENCE IN THE MATTER OF INNOVATION AND INTERNATIONAL COMMERCIAL MANAGEMENT: a vision in front of the exchanges from Bogotá, Colombia”. Pilot University of Colombia. June 26, 2019 (OJEDA(a), 2019).

On the other hand, by going through phases of creation after implementation and testing, the Innovation Diamond has demonstrated with concrete results the contributions given to companies, both in the industrial sector and in the agricultural sector. On the other hand, it has already been used as theoretical support in research projects. The students have made presentations in scientific events made by and for students of the Business Administration Program of the University, Piloto de Colombia (Tubers, 2020). This tool, then, remains at the disposal of the company, the academy in general, and the institutions of the State, country to evaluate, diagnose, project strategies that in terms of Innovation have to apply Countries, cities, business sectors, companies, with low environmental impact, where innovative products, services, processes are not established, but not per se, but thinking about the environmental impact that these will create in any of the stages of the organization, to which they are integrated.

Funding. There is no funding for this research.

\section{References}

1. Ebdrup, N. (2014). Minimal corruption in Denmark began with the absolute monarchy. Science Nordic. Available at: [Link]

2. Transparency International (s.f.). Corruption Perceptions Index. Available at: [Link]

3. ITU, International Telecomunications Union. (s.f.). Global Cibersecurity Index. Available at: [Link]

4. Journal, H. a. (s.f.). Índice De Libertad Económica [Index of Economic Freedom]. Available at: [Link]

5. OECD (2010). SMEs. Entrepreneurship and Innovation. Available at: [Link]

6. OECD (2019). OECD.Stat. Available at: [Link]

7. OJEDA(b), F.A. (2019). Analysis and Strategic Projection of GRUPO SASA S.A.S, based on an approach, contributed by the Innovation Diamond. Institutional, Bogotá. In custody of the Business Administration Program. Research Office, Pilot University of Colombia.

8. OJEDA(a), F.A. (2019). Estado del Arte y Marco Teórico, Las Empresas Como Referente En Materia De Innovación Y De Gestion Comercial Internacional: una visión frente a los intercambios desde Bogotá, Colombia. Presentado al Programa de Administración de Empresas y la Oficina de Investigación, Universidad Piloto de Colombia, Universidad Piloto de Colombia, Cundinamarca, Bogotá. [State of the Art and Theoretical Framework, The Companies as a Reference in the Matter of Innovation and International Commercial Management: a vision in front of the exchanges from Bogotá, Colombia. Presented to the Business Administration Program and the Research Office, Universidad Piloto de Colombia. Bogota Colombia. Available at: [Link]

9. OJEDA(b), F.A. (2014). La ciudad más grande del mundo Chogqing. Bogotá: Universidad Piloto de Colombia. [The largest city in the world Chogqing. Bogotá: Pilot University of Colombia]. 54 p. [Google Scholar

10.OJEDA(c), F.A. (2014). Despegue De Las Grandes Marcas Y Estrategias Japonesas: aportes a una manera de hacer los negocios y construir empresas para toda la vida.. [Take Off Of The Big Japanese Brands And 
Strategies: Contributions in One Way of doing business and building companies for life]. Bogotá. Colombia: Universidad Piloto de Colombia. 94 p. [Google Scholar]

11.OJEDA(d), F.A. (2014). La evolución histórica del modelo de las Firmas Asiáticas. [The historical evolution of the model of Asian Firms]. Bogotá: Universidad Piloto de Colombia. 99 p. [Google Scholar]

12.OJEDA(e), F.A. (2014). El nuevo milagro asiático, del destrozo total y el estado fallido al último modelo del éxito empresarial asiático. [The new Asian miracle, from the total destruction and the failed state to the latest model of Asian business success]. Bogotá: Universidad Piloto de Colombia. 53 p. [Google Scholar]

13.OJEDA(f), F.A. (2014). Bangalore El Silicon Valley De La India: ina ciudad que logra potenciar sus posibilidades competitivas y comparativas históricas al nivel de las grandes del mundo. [Bangalore The Silicon Valley of India: a city that manages to boost its historical competitive and comparative possibilities at the level of the world's largest]. Bogotá, Colombia: Universidad Piloto de Colombia. 53 p. [Google Scholarl

14.OJEDA(g), F.A. (2014). El modelo empresarial de la China del siglo XXI. [The business model of China in the 21st century]. Bogotá: Universidad Piloto de Colombia. 99 p. [Google Scholar]

15.OJEDA(h), F.A. (2018). El secreto mejor gaurdado de Asia: TAIWAN. [Asia's best-kept secret: TAIWAN]. Bogotá: Universidad Piloto de Colombia. [Google Scholar]

16.OJEDA(i), F.A. (2015). Entorno De Los Negocios. [Business Environment]. Bogotá: Universidad Piloto de Colombia. 150 p. [Google Scholar]

17.OJEDA, F.A. (2014). La Crisis Asiática. [The Asian crisis]. Bogotá: Universidad Piloto de Colombia. Available at: [Link]

18.OJEDA, F.A. (2020). Análisis y Proyección Estratégica del SECTOR LÁCTEO- Cundinamarca, a aprtir de un enfoque, del Diamante de la Innovación. [Analysis and Strategic Projection of the DAIRY SECTORCundinamarca, to aprtir of an approach, the Innovation Diamond]. Universidad Piloto de Colombia, Proyección Social. Bogotá: Universidad Piloto de Colombia.

19.Tubers, S. (2020). El diamante de la innovación un comparativo entre Colombia y Costa Rica. Available at: [Link]

20.Universidad de Cornell, INSEAD, Organización Mundial de Propiedad Intelectual. (s.f.). GLOBAL INNOVATION INDEX. Available at: [Link]

21.World Bank (s.f.). GDP (current US\$). Available at: [Link]

22.World Economic Forum (s.f.). The Global Competitiveness Report. Available at: [Link].

23.Worlds of Education (2015). The Learning Curve of Pearson. Available at: [Link] 
Table 2. The Green Diamond of Innovation

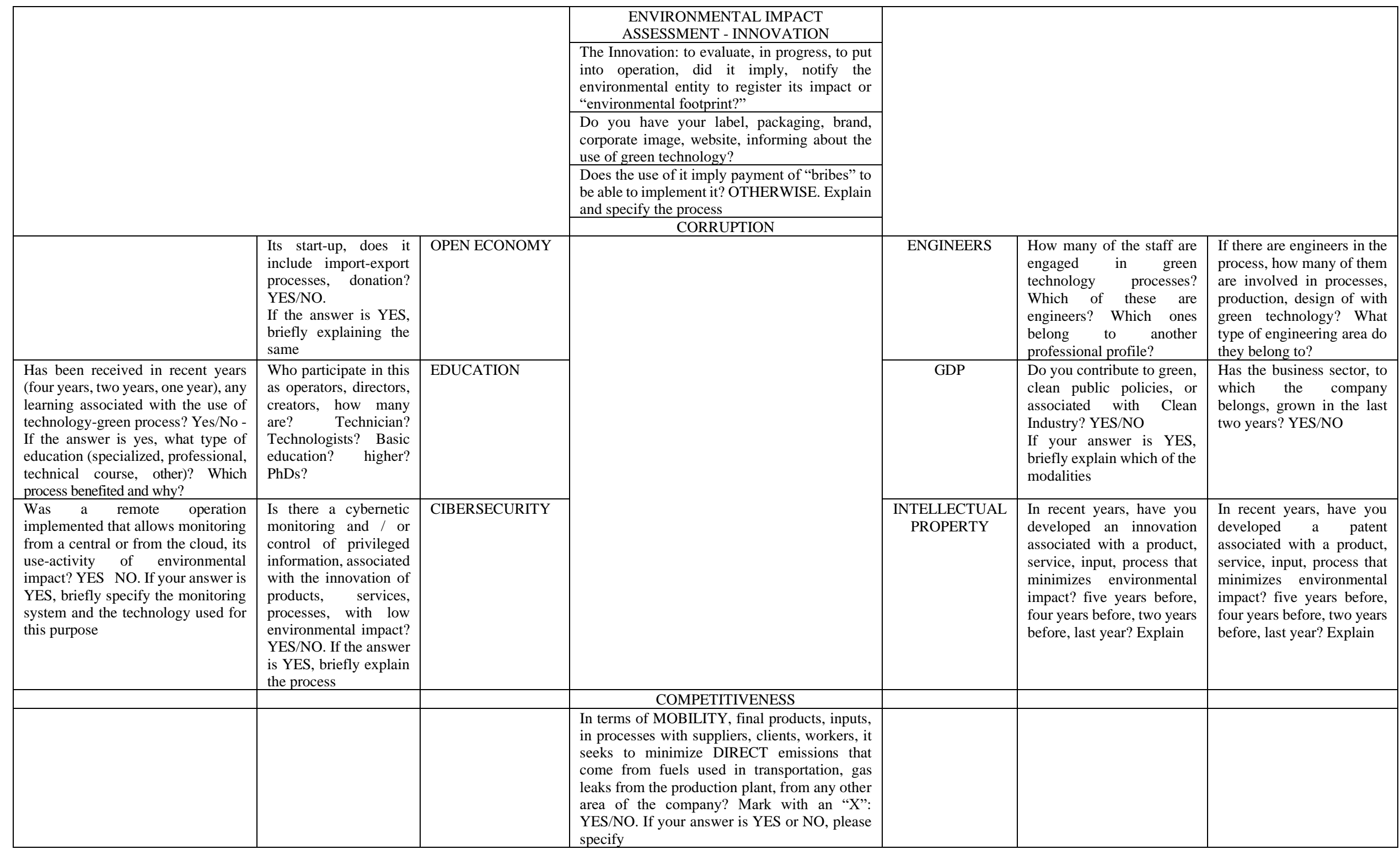




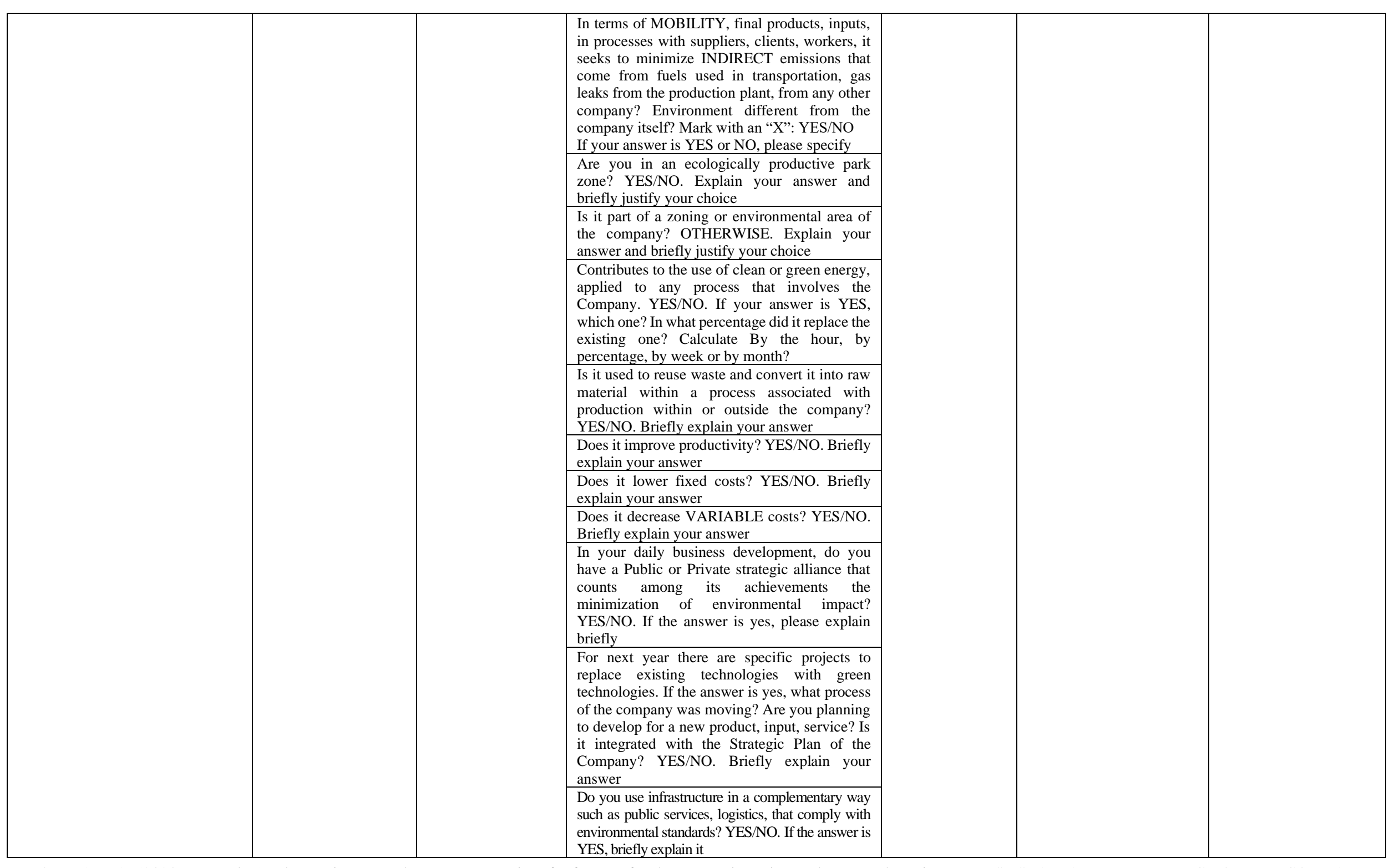

Source: OJEDA, F.A. (2020, November). The Environmental Impact, as a point of reference for the Innovation Diamond. Research Project: THE SUSTAINABLE REFERENCE OF THE COMPANY IN COLOMBIA: support of the Innovation of the XXI Century. Business Administration Program. Research Office. Pilot university of Colombia. MANAGEMENT: a vision in front of the exchanges from Bogotá, Colombia. Business Administration Program. Research Office. Pilot University of Colombia. 